\title{
Sifat Fisik Tanah Pada Lahan Agroforestri dan Hutan Lahan Kering Sekunder di Sub Das Wuno, Das Palu
}

\author{
Naharuddin', Indah Sari ${ }^{2}$, Herman Harijanto $^{3}$, dan Abdul Wahid ${ }^{4}$ \\ 1,2,3,4 Jurusan Kehutanan, Fakultas Kehutanan, Universitas Tadulako \\ Jl. Soekarno-Hatta Km. 9 Palu, Sulawesi Tengah, 94118 \\ ${ }^{1}$ Email: nahar.pailing@gmail.com
}

\begin{abstract}
Changes in land use have an impact on the physical properties of the soil and on the hydrological processes of watersheds. This research aims to compare the physical properties of soil in agroforestry land use and secondary dryland forest in Wuno Sub-watershed, Sigi Regency. The research method uses a survey method followed by sampling for analysis materials in the laboratory. Soil analysis was carried out at the Laboratory of Soil Science, Faculty of Agriculture, Tadulako University. Determination of the location for the sampling of the soil was determined purposive sampling to obtain 6 sample points. Soil samples were taken 3 times for each land use. The results showed that the soil texture on agroforestry land had a sand fraction $79.8 \%$, then a dust fraction $19.1 \%$, and a clay fraction $1.1 \%$, while on secondary dryland forest had a fraction of sand $62 \%$, dust fraction $37.2 \%$, and clay fraction $0.8 \%$. The highest permeability at a depth of $0-20 \mathrm{~cm}$ was found in agroforestry land $10.44 \mathrm{~cm} / \mathrm{hour}$, and the lowest in secondary dryland forest was $2.29 \mathrm{~cm} /$ hour. Bulk density in agroforestry land is $1.41 \mathrm{~g} / \mathrm{cm}^{3}$, secondary dryland forest is $1.64 \mathrm{~g} / \mathrm{cm}^{3}$. The soil porosity in the agroforestry section was $40.85 \%$, while the secondary dryland forest was $22.90 \%$. Soil organic matter in agroforestry land is $4.23 \%$, while secondary dryland forest is $3.81 \%$. There is no significant difference in the parameters of the physical properties of the soil between the two land uses, both in soil texture, bulk density, and organic matter, however, the value of soil porosity and permeability in agroforestry land is higher than secondary dryland forest.
\end{abstract}

Keywords: Agroforestry Land, Bulk Density, Organic Matter, Secondary Dry Land Forest, Soil Physical Properties.

\begin{abstract}
ABSTRAK
Perubahan penggunaan lahan memiliki dampak terhadap sifat fisik tanah maupun proses hidrologi daerah aliran sungai. Penelitian ini bertujuan untuk membandingkan sifat fisik tanah pada penggunaan lahan agroforestri dan hutan lahan kering sekunder di Sub-DAS Wuno, Kabupaten Sigi. Metode penelitian menggunakan metode survei dilanjutkan dengan pengambilan sampel untuk bahan analisis di Laboratorium. Analisis tanah dilakukan di Laboratorium IImu Tanah, Fakultas Pertanian, Universitas Tadulako. Penentuan lokasi pengambilan sampel tanah ditentukan secara sengaja untuk mendapatkan 6 titik sampel. Pengambilan sampel tanah dilakukan 3 kali untuk setiap penggunaan lahan. Hasil penelitian menunjukkan bahwa tekstur tanah pada lahan agroforestri memiliki fraksi pasir $79,8 \%$, kemudian fraksi debu $19,1 \%$, dan fraksi liat $1,1 \%$, sedangkan hutan lahan kering sekunder memiliki fraksi pasir $62 \%$, fraksi debu $37,2 \%$, dan fraksi liat 0,8\%. Permeabilitas tertinggi pada kedalaman $0-20 \mathrm{~cm}$ ditemukan di lahan agroforestri 10,44 cm/jam, dan terendah di hutan lahan kering sekunder adalah $2,29 \mathrm{~cm} / \mathrm{jam}$. Bobot isi pada lahan agroforestri adalah $1,41 \mathrm{~g} / \mathrm{cm}^{3}$, hutan lahan kering sekunder adalah $1,64 \mathrm{~g} / \mathrm{cm}^{3}$. Porositas tanah lahan agroforestri adalah $40,85 \%$, sedangkan hutan lahan kering sekunder adalah $22,90 \%$. Bahan organik tanah pada lahan agroforestri adalah $4,23 \%$, sedangkan hutan lahan kering sekunder adalah $3,81 \%$. Tidak terdapat perbedaan yang cukup siginfikan terhadap parameter sifat fisik tanah diantara kedua penggunaan lahan baik pada tekstur tanah, bobot isi, dan bahan organik, namun demkian nilai porositas tanah dan permeabilitas pada lahan agroforestri lebih tinggi dibandingkan dengan hutan lahan kering sekunder.
\end{abstract}


Kata kunci: Lahan Agroforestri, Bobot Isi, Bahan Organik, Hutan Lahan Kering

Sekunder, Sifat Fisik Tanah.

\section{Pendahuluan}

Konversi hutan menjadi lahan pertanian berpengaruh terhadap penurunan kualitas lahan (Song dan Liu, 2017; Naharuddin et al. 2018; Li et al. 2020). Hal ini menyebabkan serasah dan bahan organik tanah berkurang karena deforestasi, yang biasanya dilakukan dengan cara tebas bakar. Konversi hutan menjadi lahan pertanian tanaman semusim melibatkan faktor-faktor yang kompleks, yaitu pengelolaan lahan, penanaman, pemeliharaan serta pemanenan budidaya yang diusahakan memberikan pengaruh tertentu terhadap sifat tanah (Assefa et al. 2017; Asdak, 2018; Veldkamp et al. 2020).

Penelitian karakteristik sifat fisik tanah perlu dilakukan karena sangat berguna untuk menentukan kemampuan fisik tanah yang berperan dalam konservasi tanah dan air. Sifat fisik tanah memiliki banyak kegunaan sesuai dengan kemampuannya, yaitu kemampuan untuk mengalirkan dan menyimpan air, penetrasi akar yang mudah, aerasi, dan kemampuan menahan retensi serta nutrisi tanaman, hal tersebut berkaitan erat dengan kondisi sifat fisik tanah. Sebagai sumber daya alam utama, tanah menempati posisi penting dalam pembangunan lingkungan yang berkelanjutan. Penurunan kapasitas tanah dapat mengurangi kemampuan fungsi lingkungan (Nursa'ban, 2006).

Variasi karakteristik lahan berupa bentuk topografi, iklim, geologi, tanah dan vegetasi yang meliputi tanah di daerah aliran sungai (DAS) akan mempengaruhi sifat fisik tanah. Selain itu, vegetasi bisa membuat kondisi tanah jadi lebih gembur dan memperhalus agregat. Tanah yang lebih halus akan menyebabkan bobot isi tanah berkurang dan porositas tinggi. Hal ini akan menghasilkan banyak makropori dan mikropori, yang akan membuat penetrasi lebih cepat dan meningkatkan kelembaban tanah. Sifat fisik tanah menentukan penetrasi akar tanaman, retensi air, drainase, aerasi serta nutrisi tanaman (Asdak, 2018). Sifat fisik tanah pada penggunaan lahan sawah, lahan tegalan, lahan kebun campuran dan lahan yang mengalami gangguan seperti kebakaran hutan dengan masing-masing kelerengan yang berbeda, mempunyai sifat fisik yang bervariasi, tekstur tanah didominasi fraksi debu dan pasir dengan kelas tekstur lempung berdebu, mempunyai bahan organik sedang, permeabilitas sedang, porositas yang kurang baik, kapasitas lapang dan kadar air jenuh rendah sampai tinggi (Delsiyanti, 2016; Murtinah et al. 2017).

Sub DAS Wuno adalah satu diantara Sub DAS yang ada di DAS Palu, secara administrasi berada di Kabupaten Sigi, dan memiliki topografi yang berbeda-beda, baik dari kemiringan lereng, panjang lereng dan posisi lerengnya. Bagian hulu Sub-DAS Wuno berfungsi sebagai daerah tangkapan air untuk dialirkan ke lahan pertanian di bagian hilir 
dan untuk kebutuhan masyarakat. Sebagian besar lahan yang berada di Sub DAS Wuno bagian hulu yaitu areal hutan dan semak belukar sebagai vegetasi pelindung tanah yang mampu menekan laju erosi (Naharuddin, 2018; Naharuddin et al. 2019). Pada 10 tahun terakhir ini, kawasan Sub DAS Wuno terjadi alih fungsi lahan hutan menjadi lahan pertanian yang berpengaruh pada penurunan kualitas lahan.

Karakteristik penggunaan lahan yang berbeda serta kerapatan tajuk tanaman yang berbeda akan menyebabkan sifat fisik tanah yang berbeda dan kapasitas penyaluran air tanah, dan turut mempengaruhi cadangan air tanah, drainase, aliran permukaan dan erosi, dan produktivitas tanaman (Naharuddin, 2018; Risamasu dan Marlissa, 2020). Oleh karena itu, perubahan sifat-sifat tanah akibat penggunaan lahan menarik untuk dilakukan kajian yang mendalam. Tujuan penelitian ini untuk membandingkan sifat fisik tanah pada penggunaan lahan agroforestri dan hutan lahan kering sekunder di Kawasan Sub-DAS Wuno Kabupaten Sigi.

\section{$2 \quad$ Metode Penelitian}

\section{Waktu dan Tempat}

Penelitian ini dilaksanakan dari bulan Oktober 2019 hingga Maret 2020 di Kawasan Sub DAS Wuno, pada lahan agroforestri (kemiri dan kakao) dan hutan lahan kering sekunder (Gambar 1)

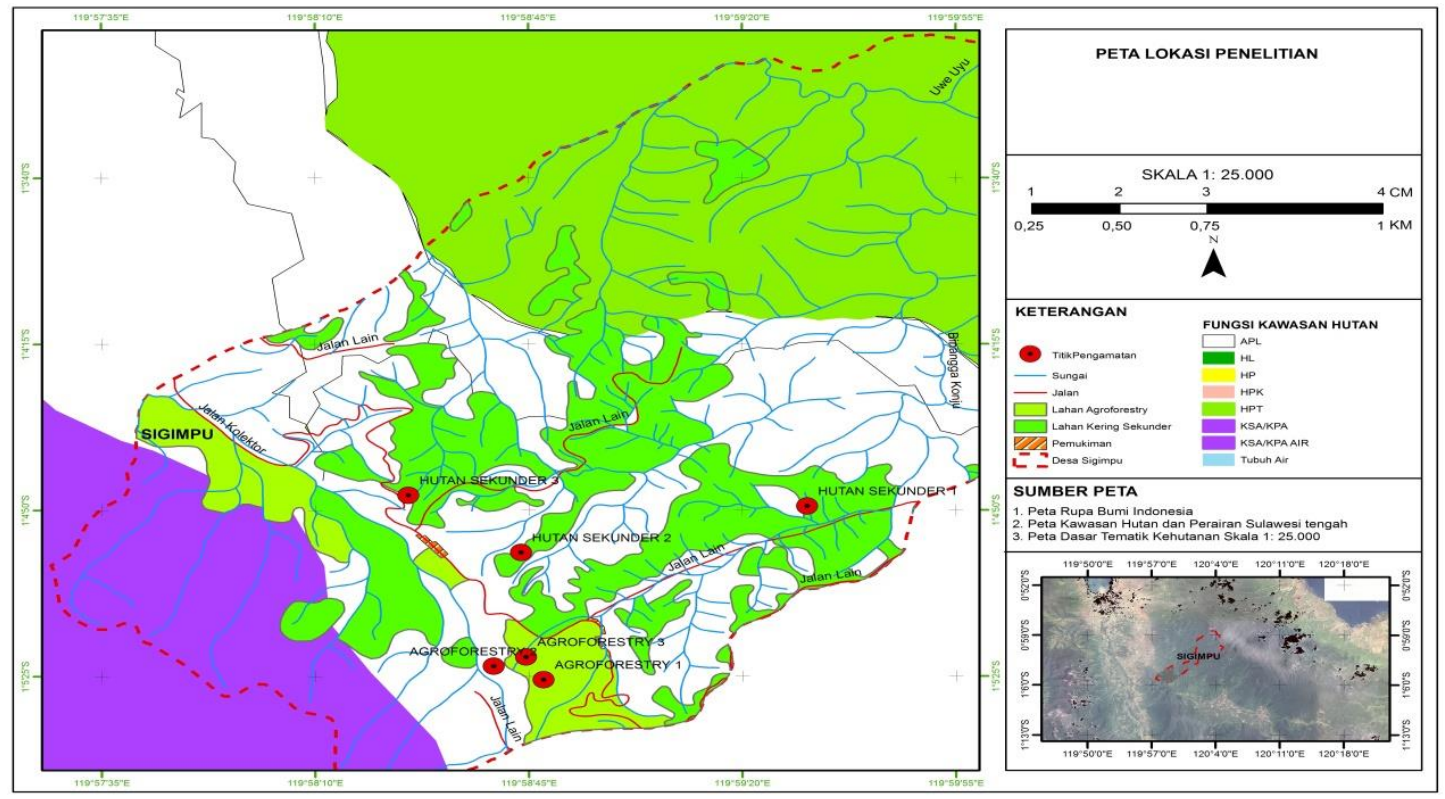

Gambar 1. Peta Lokasi Penelitian 


\section{Bahan dan Alat}

Bahan-bahan yang digunakan dalam penelitian ini adalah sebagai berikut:

1. Fiber, untuk menyimpan sampel tanah utuh

2. Kantong plastik es, untuk menyimpan sampel tanah

3. Kertas label, untuk memberi nama pada sampel

4. Sampel tanah utuh dan tanah tidak utuh

5. bahan kimia yang digunakan dalam analisis laboratorium Alat-alat yang digunakan pada penelitian ini sebagai berikut:

1. Alat tulis sebagai pencatat data

2. Aplikasi Avenza Maps untuk menentukkan titik koordinat titik pengambilan sampel tanah

3. Ayakan untuk memisahkan tanah kasar dan tanah halus

4. Cutter untuk meratakan tanah

5. Kalkulator sebagai alat hitung

6. Kamera untuk dokumentasi penelitian

7. Ring sampel digunakan untuk mengambil sampel tanah utuh

8. Sendok semen digunakan untuk menggali tanah

9. Stopwatch sebagai alat untuk menghitung waktu penambahan air secara kontinu pada tingkat air konstan

10. Tabung ukur yang digunakan untuk mengukur air secara terus menerus disuntikkan ke dalam tabung permeameter

11. Timbangan sebagai alat timbangan tanah

12. Permeameter sebagai alat untuk mengukur permeabilitas

\section{Prosedur Penelitian}

Pengambilan contoh tanah utuh dengan menggunakan ring sampai kedalaman 0$20 \mathrm{~cm}$ dari lapisan tanah bagian atas pada kedua penggunaan lahan, pengambilan sampel tanah dilakukan dalam 2 unit lahan, yaitu lahan agroforestri dan hutan lahan kering sekunder. Pengambilan sampel tanah dilakukan sebanyak 3 kali pengulangan berdasarkan tutupan lahan. Sehingga jumlah sampel tanah utuh yang didapatkan sebanyak 6 titik sampel. Pengambilan contoh tanah utuh untuk pengukuran permeabilitas, bobot isi dan porositas total. Pengambilan contoh selanjutnya adalah pengambilan contoh tanah tidak utuh untuk penetapan tekstur dan kandungan bahan organik tanah.

\section{Metode Analisis Sampel Tanah}

\section{Tekstur}

Analisis tekstur tanah dilakukan dengan menggunakan metode pipet (Hanafiah, 2005; Sugirahayu dan Rusdiana, 2011). 


\section{Bobot isi}

Untuk menetapkan bobot isi (kepadatan tanah atau berat jenis volume tanah) dengan satuan $\mathrm{g} / \mathrm{cm}^{3}$ dapat di hitung mengunakan metode gravimetris (Sugirahayu dan Rusdiana, 2011; Latiefuddin et al., 2013).

\section{Porositas Tanah}

Porositas dihitung menggunakan rumus sesuai petunjuk Kusuma et al., (2013).

$$
\text { Porositas tanah }=\left\{(1,0)-\left(\frac{\text { Bulk density }}{\text { Partikel density }} \times 100 \%\right)\right.
$$

\section{Permeabilitas}

Menurut Kusuma et al., (2013), permeabilitas tanah dapat dihitung dengan menggunakan rumus berikut:

$$
\text { Permeabilitas }(K)=\left(\frac{Q}{t}+\frac{I}{h}+\frac{I}{A}\right) \mathrm{cm} / j a m
$$

Keterangan:

$\mathrm{K}=$ Permeabilitas,

$\mathrm{Q} \quad=$ Aliran air di setiap pengukuran $(\mathrm{ml})$,

$\mathrm{t}=$ Waktu pengukuran (jam),

I = Ketebalan sampel tanah $(\mathrm{cm})$,

$\mathrm{h} \quad=$ Tinggi permukaan air dari permukaan sampel tanah $(\mathrm{cm})$,

$\mathrm{A}=$ Luas permukaan sampel tanah $/ \pi \cdot r^{2}$.

\section{Bahan Organik}

Analisis kandungan bahan organik tanah menggunakan metode Wlkey and Black (Foth, 1994; Tangketasik et al. 2012)

\section{Hasil Dan Pembahasan}

\section{Sifat Fisik Tanah Pada Berbagai Penggunaan Lahan}

Sifat fisik tanah yang diamati meliputi tekstur tanah, permeabilitas, porositas tanah, bobot isi, dan bahan organik pada penggunaan lahan agroforestri dan lahan hutan kering sekunder. Analisis sifat fisik tanah dari masing-masing lokasi penelitian disajikan pada Tabel 1.

\begin{tabular}{|c|c|c|c|c|c|c|c|c|}
\hline \multirow{2}{*}{$\begin{array}{c}\text { Kode } \\
\text { Sampel } \\
\text { Penggunaan } \\
\text { Lahan }\end{array}$} & \multirow{2}{*}{$\begin{array}{l}\text { Permeabilitas } \\
\text { (cm/jam) }\end{array}$} & \multirow{2}{*}{$\begin{array}{l}\text { Bobot isi } \\
\left(\mathrm{g} / \mathrm{cm}^{3}\right)\end{array}$} & \multirow{2}{*}{$\begin{array}{c}\text { Porositas } \\
\text { Tanah } \\
(\%)\end{array}$} & \multirow{2}{*}{$\begin{array}{c}\text { Bahan } \\
\text { Organik } \\
(\%)\end{array}$} & \multicolumn{3}{|c|}{ Tekstur (\%) } & \multirow[b]{2}{*}{ Ket. } \\
\hline & & & & & Pasir & Debu & Liat & \\
\hline AGR 1 & 10,44 & 1,37 & 40,85 & \multirow{4}{*}{4,23} & \multirow{4}{*}{79,8} & \multirow{4}{*}{19,1} & \multirow{4}{*}{1,1} & \multirow{4}{*}{$\begin{array}{l}\text { Lempung } \\
\text { berpasir }\end{array}$} \\
\hline AGR 2 & 9,77 & 1,41 & 38,98 & & & & & \\
\hline AGR 3 & 8,76 & 1,38 & 40,41 & & & & & \\
\hline HLKS 1 & 2,66 & 1,61 & 24,58 & & & & & \\
\hline HLKS 2 & 2,29 & 1,64 & 22,90 & \multirow[b]{2}{*}{3,81} & \multirow[b]{2}{*}{62} & \multirow[b]{2}{*}{37,2} & \multirow[b]{2}{*}{0,8} & \multirow[b]{2}{*}{ Lempung } \\
\hline HLKS 3 & 6,05 & 1,54 & 27,77 & & & & & \\
\hline
\end{tabular}

Tabel 1. Hasil analisis sifat fisik tanah pada beberapa penggunaan lahan

Keterangan: AGR $=$ Agroforestri, HLKS $=$ Hutan Lahan Kering Sekunder 


\section{Tekstur}

Tekstur tanah menunjukkan sifat partikel halus atau kasar, tekstur yang lebih khas ditentukan dengan mempertimbangkan kandungan pasir, debu, dan liat yang terkandung dalam tanah. Tekstur digunakan untuk menunjukkan ukuran partikel tanah, terutama dalam perbandingan relatif berbagai kategori tanah.

Berdasarkan hasil penelitian pada Tabel 1, menunjukkan bahwa ada dua kategori tekstur tanah yang berbeda di dua lahan, yaitu lempung berpasir dan lempung. Kelas tekstur lempung berpasir terdapat pada lahan agroforestri dengan memiliki fraksi pasir $79,8 \%$, kemudian fraksi debu 19,1\%, dan fraksi liat 1,1\% dan kelas tekstur lempung terdapat pada lahan hutan kering sekunder dengan memiliki fraksi pasir $62 \%$, fraksi debu $37,2 \%$, dan fraksi liat 0,8\%. Dengan demikian pada kedua lahan memiliki nilai tekstur dominan fraksi pasir dibandingkan dengan fraksi debu dan liat. Semakin rendah fraksi liat atau semakin tinggi nilai fraksi pasir akan mempengaruhi karakteristik lahan seperti daya menyimpan air, porositas, bahan organik dan lainnya. Hal ini tersebut, sejalan dengan penelitian Hanafiah (2005), menyatakan bahwa semakin tinggi persentase fraksi pasir dalam tekstur tanah, semakin mudah air di dalam tanah dapat melewatinya. Tetapi kemampuan tanah untuk mengalirkan air tidak hanya tergantung pada tekstur tanah. Ada banyak faktor lain yang mempengaruhi, yaitu porositas, bahan organik, dan kontinuitas pori tanah.

Rendahnya kandungan fraksi liat pada kedua lahan berpengaruh terhadap formasi agregat tanah. Posisi dan komposisi bahan organik sangat menentukan proses pembentukan stabilitas dan distribusi egregat (Nurida dan Kurnia, 2009; Juarsah, 2016). Tanah berpasir di kedua jenis pengunaan lahan yaitu agroforestri dan hutan lahan kering sekunder sulit menyerap air dan nutrisi karena butiran besar dan luas permukaan kecil persatuan berat. Tanah yang di dominasi fraksi pasir bersifat porous yang memiliki pori aerasi tinggi. Sifat aerasi yang lancar dapat meningkatkan oksidasi bahan organik. Hal tersebut sejalan dengan Afriani dan Juansyah (2016), bahwa tanah dominan fraksi pasir mempunyai kapasitas menahan air rendah dan kandungan bahan organik juga rendah. Tanah liat memiliki luas permukaan yang besar per satuan berat, sehingga memiliki kemampuan untuk menahan air dan memberikan nutrisi yang tinggi. Selanjutnya menurut Agus et al., (2006) tanah yang bertekstur halus lebih aktif dalam proses reaksi kimia daripada tanah yang bertekstur kasar.

\section{Permeabilitas}

Berdasarkan hasil penelitian pada Tabel 1, permeabilitas memiliki kriteria sedang hingga agak cepat. Nilai permeabilitas tertinggi yang ditemukan di lahan agroforestri dengan nilai 10,44 cm/jam. Sedangkan nilai permeabilitas terendah di hutan lahan kering sekunder dengan nilai $2,29 \mathrm{~cm} / \mathrm{jam}$. Hutan lahan kering sekunder memiliki nilai 
permeabilitas terendah, hal ini disebabkan rendahnya bobot isi yang dimiliki oleh lahan.

Selain itu, nilai bobot isi yang tinggi pada lahan ini turut mempengaruhi nilai permeabilitas yang diperoleh.

Lahan agroforestri memiliki nilai permeabilitas lebih tinggi dibandingkan hutan lahan kering sekunder, karena ruang pori total serta kandungan bahan organik yang dimiliki oleh lahan agroforestri lebih tinggi daripada hutan lahan kering sekunder. Kadar bahan organik yang lebih tinggi di lahan agroforestri telah menghasilkan bobot isi yang lebih rendah dan porositas yang tinggi daripada hutan lahan kering sekunder, sehingga permeabilitas di lahan agroforestri lebih tinggi dari pada hutan lahan kering sekunder. Permeabilitas tanah di pengaruhi oleh kandungan bahan organik, bobot isi, porositas, dan stabilitas agregat tanah. Permeabilitas yang berkisaran sedang hingga cepat pada kedua penggunaan lahan yang di pengaruhi oleh kandungan bahan organik yang berharkat rendah hingga sedang.

Alih fungsi lahan dari hutan lahan kering primer ke hutan lahan kering sekunder sesuai Tabel 1 memberikan pengaruh terhadap sifat fisik tanah terutama permeabilitas. Hal tersebut sejalan dengan penelitian Junaedi (2010), menunjukkan bahwa alih fungsi hutan menjadi lahan pertanian akan menimbulkan berbagai efek negatif, terutama degradasi lahan akibat erosi. Demikian juga, Arifin (2010) menjelaskan bahwa permeabilitas yang rendah akan menimbulkan limpasan permukaan yang lebih tinggi, yang pada gilirannya akan meningkatkan limpasan permukaan dan menyebabkan peningkatan erosi. Faktor yang mempengaruhi permeabilitas tanah yaitu tekstur tanah. Tekstur tanah memainkan peran penting dalam menentukkan permeabilitas, dan tanah dengan kadar pasir yang lebih tinggi akan meningkatkan permeabilitas dari pada tanah dengan kandungan tanah liat yang lebih tinggi (Evarnas et al., 2014).

\section{Porositas Tanah}

Porositas tanah adalah rasio volume semua pori dalam volume tanah, yang dinyatakan dalam persentase. Porositas mencakup ruang antara pasir, debu, dan partikel tanah liat serta ruang antara agregat tanah (Puja, 1989). Menurut Evarnaz et al. (2014), bahan organik dengan porositas tinggi mengurangi kepadatan tanah, karena bahan organik jauh lebih ringan daripada mineral, dan bahan organik juga meningkatkan porositas tanah. Menurut penelitian Nugroho (2009), porositas tanah dengan struktur detrital (granula) lebih tinggi daripada tanah terstruktur padat.

Hasil penelitian pada Tabel 1, menunjukkan bahwa porositas tanah yang lebih tinggi terdapat pada lahan agroforestri $40.85 \%$, dan yang terendah terdapat pada hutan lahan kering sekunder $22.90 \%$. Hal ini dipengaruhi oleh tekstur yang didominasi oleh pasir dan debu serta bobot volume isi yang relatif rendah hingga tinggi. Tingkat porositas tanah tergantung pada bobot isi. semakin besar bobot isi tanah, semakin rendah nilai porositas 
tanah. Sebaliknya semakin rendah porositas tanah akan meningkatkan volume tanah yang tidak diisi dengan zat padat (termasuk mineral dan bahan organik), yang disebut ruang pori. Ruang pori total terdiri dari partikel pasir, debu, dan tanah liat dan agregat tanah. Jika distribusi ukuran pori tanah terutama didominasi oleh makropori, biasanya tanah memiliki kapasitas menyimpan air yang rendah (Arifin, 2011).

\section{Bobot isi}

Bobot Isi $(\mathrm{BI})$ ialah berat padatan (di bawah pengeringan konstan) dibagi dengan total volume (padatan + pori-pori). Kisaran tanah BI yang ideal adalah 1,3-.1,35 g/. $\mathrm{cm}^{3}$, dan kisaran tanah $\mathrm{BI}>1,65 \mathrm{~g} / \mathrm{cm}^{3}$ untuk pasir: 1,0-1,6 g/ $/ \mathrm{cm}^{3}$ di tanah liat dengan $\mathrm{BO}$ sedang dan tinggi, BI mungkin kurang dari $1 \mathrm{~g} / \mathrm{cm}^{3}$ di tanah BO tinggi (Tarigan et al., 2015).

Hasil analisis labolatorium pada (Tabel 1), nilai bobot isi memiliki nilai berbeda. Hutan lahan kering sekunder memiliki nilai bobot isi tertinggi dengan nilai $1,64 \mathrm{~g} / \mathrm{cm}^{3}$ dengan kedalaman 0-20 cm, dan nilai bobot isi terendah pada lahan agroforestri yaitu dengan nilai $1,37 \mathrm{~g} / \mathrm{cm}^{3}$ dengan kedalaman $0-20 \mathrm{~cm}$. Tinggi rendahnya nilai bobot isi yang terlihat pada Tabel 1 dapat dijadikan sebagai indikator kesuburan tanah. Tanah dengan sedikit kandungan bahan organik biasanya memiliki nilai bobot isi tanah yang lebih tinggi, sehingga bobot isi tanah yang lebih rendah dapat meningkatkan air ke dalam pori-pori tanah, mendorong proses pemupukan dan meningkatkan tingkat pemanfaatan oksigen di dalam tanah.

Bobot isi tanah mineral memiliki nilai mulai dari 1-6.6 gr/ $\mathrm{cm}^{3}$, sedangkan tanah organik biasanya memiliki nilai bobot isi antara 0,1-0,9 gr/ $\mathrm{cm}^{3}$. Bobot isi dipengaruhi oleh tekstur, struktur dan isi bahan organik. Selain itu, karena pengelolaan tanah dan praktek budidaya dapat merubah bobot isi dengan cepat (Hardjowigeno, 2007). Bobot isi sangat erat kaitannya dengan permeabilitas dan porositas. Jika bobot isi tinggi, permeabilitas dan porositas rendah. Sebaliknya, jika permeabilitas dan porositas tinggi, bobot isi rendah. Semakin tinggi bobot isi, semakin padat tanah, maka semakin rendah permeabilitas tanah (Arabia et al., 2012; Murtinah dan Komara, 2019; Pivić et al. 2020). Rauf et al., (2015), menyatakan bahwa semakin rendah nilai bobot isi maka tanah semakin gembur. Semakin padat tanah, semakin tinggi kepadatan tanah, yang berarti lebih sulit untuk menembus air atau ditembus akar tanaman. Pernyataan tersebut, juga didukung oleh Putra et al., (2016) bahwa kemampuan tanah dalam meloloskan air erat kaitannya dengan peran bobot isi pada tinggi rendahnya kepadatan tanah.

\section{Bahan Organik}

Hasil penelitian pada Tabel 1, menunjukkan bahwa kandungan bahan organik lahan agroforestri adalah 4,23\%, dan hutan lahan kering sekunder 3,81\%, keduanya memiliki kandungan rendah hal tersebut diduga dipengaruhi oleh kandungan liat pada 
kedua lahan rendah (Tabel 1) yakni masing-masing pada lahan agroforestri 1,1\% dan pada hutan lahan kering sekunder $0,8 \%$. Hasil tersebut sejalan dengan pendapat Supriyadi, (2008) peningkatan kandungan bahan organik seiring dengan meningkatnya fraksi liat, ikatan antara fraksi liat dan bahan organik melindungi bahan tersebut dari aksi dekomposisi hara oleh mikrobia tanah. Selanjutnya menurut Power dan Prasad (1997) kondisi iklim yang sama kandungan bahan organik tanah dengan tekstur halus (liat) dapat mencapai 2-4 kali kandungan bahan organik di dalam tanah.

Jika dibandingkan pada kedua lahan kandungan bahan organik tertinggi pada lahan agroforestri disebabkan tajuk tanaman pada lahan agroforestri terbilang rapat yang didominasi oleh tanaman yang bertajuk tinggi, sehingga serasah menjadi bahan organik tanah yang lebih tinggi. Berbeda halnya dengan hutan lahan kering sekunder, kandungan bahan organik rendah karena lahan kering sekunder ditanami dengan tanaman musiman dan bertajuk rendah. Selain itu pengolahan tanah secara intensif pada lahan hutan kering sekunder menyebabkan dekomposisi bahan organik lebih cepat dibandingkan dengan penggunaan lahan lainnya.

Menurut pendapat Monde et al., (2008), bahwa karena pasokan bahan organik yang berkelanjutan dari vegetasi hutan, akumulasi lahan hutan tinggi, dan kandungan bahan organik di lahan hutan sangat tinggi. Keadaan stabil ini menyebabkan bahan organik membusuk secara alamai, dan sebaliknya. ini terjadi dengan cepat, karena ada pengelolaan lahan terbuka, dan suhu tanah juga naik. Kandungan bahan organik sangat penting dalam pengelolaan tanah dan tanaman. Menurut Supriyadi, (2008) kandungan karbon dalam tanah mencerminkan kandungan bahan organik dalam tanah, juga merupakan tolak ukur yang penting dalam pengelolaan tanah dan secaran langsung ataupun tidak langsung berpengaruh terhadap kualitas tanah.

\section{Kesimpulan}

Penggunaan lahan agroforestri memiliki tekstur tanah lempung berpasir, permeabilitas tanah tergolong agak cepat, porositas tanah yang buruk, bobot isi relatif tinggi, dan bahan organik tanah tinggi. Penggunaan hutan lahan kering sekunder memiliki kelas tekstur lempung, permeabilitas tanah tergolong sedang, porositas tanah memiliki kelas sangat jelek, bobot isi relatif sedang, dan kandungan bahan organik tanah tergolong rendah. Sifat fisik tanah pada lahan agroforestri lebih baik dibandingkan dengan penggunaan hutan lahan kering sekunder terutama pada parameter porositas tanah dan permeabilitas. 


\section{Daftar Pustaka}

Afriani, L., \& Juansyah, Y. (2016). Pengaruh fraksi pasir dalam campuran tanah lempung terhadap nilai cbr dan indeks plastisitas untuk meningkatkan daya dukung tanah dasar. Rekayasa: Jurnal IImiah Fakultas Teknik Universitas Lampung, 20(1), 23-32.

Agus, F., Yutika, R. D., \& Haryati, U. (2006). Sifat fisik dan metode analisisnya. BBSDLLitbang Departemen Pertanian. Bogor.

Arabia, T., Zainabun, Z., \& Royani, I. (2012). Karakteristik tanah Salin Krueng Raya Kecamatan Mesjid Raya Kabupaten Aceh Besar. Jurnal Manajemen Sumberdaya Lahan, 1(1), 32-42.

Arifin, M. (2010). Kajian sifat fisik tanah dan berbagai penggunaan lahan dalam hubungannya dengan pendugaan erosi tanah. Jurnal Pertanian Mapeta, 12(2), 111115.

Arifin, Z. (2011). Analisis nilai indeks kualitas tanah entisol pada penggunaan lahan yang berbeda. Agroteksos, 21(1), 47-54

Asdak, C. (2018). Hidrologi dan daerah aliran sungai. Yogyakarta: Gadjah Mada University Press.

Assefa, D., Rewald, B., Sandén, H., Rosinger, C., Abiyu, A., Yitaferu, B., \& Godbold, D. L. (2017). Deforestation and land use strongly effect soil organic carbon and nitrogen stock in Northwest Ethiopia. Catena, 153, 89-99.

Delsiyanti, D., \& Rajamuddin, U. A. (2016). Sifat fisik tanah pada beberapa penggunaan lahan di Desa Oloboju Kabupaten Sigi. Agritekbis, 4(3), 227-234

Evarnaz, N., Toknok, B., \& Ramlah, S. (2014). Sifat fisik tanah di bawah tegakan eboni (Diospyros celebica Bakh) pada kawasan Cagar Alam Pangi Binangga Kabupaten Parigi Moutong. Jurnal Warta Rimba, 2 (2).

Foth, H. D. (1994). Dasar-dasar ilmu tanah edisi keenam. Jakarta: Erlangga.

Hanafiah, K. A. (2005). Dasar-dasar ilmu tanah. Jakarta: PT. Raja Grafindo Persada. Jakarta

Hardjowigeno, S. (1992). Ilmu tanah edisi ketiga. Jakarta: PT Media Utama Sarana Perkasa.

Hardjowigeno, S. (2007). Evaluasi kesesuaian lahan dan perancangan tataguna lahan. Gadjah Mada University Press.

Juarsah, I. (2016). Keragaman sifat-sifat tanah dalam sistem pertanian organik berkelanjutan. In Prosiding Seminar Nasional Pengembangan Teknologi Pertanian.

Junaedi H. (2010). Perubahan sifat fisika ultisol akibat konversi hutan menjadi lahan pertanian. J. Hidrolitan, 1(2)

Kusuma A. H, Izzati M, Saptiningsih E. (2013). Pengaruh penambahan arang dan abu sekam dengan proporsi yang berbeda terhadap permeabilitas dan porositas tanah liat serta pertumbuhan kacang hijau (Vigna radiata L). Buletin Anatomi dan Fisiologi, 21(1) 
Latiefuddin, H., Lutfi, M., \& Nugroho, W. A. (2013). Uji kinerja berbagai tipe bajak singkal dan kecepatan gerak maju traktor tangan terhadap hasil olah pada tanah mediteran. Jurnal Keteknikan Pertanian Tropis dan Biosistem, 1(3), 274-281

Li, H., Yao, Y., Zhang, X., Zhu, H., \& Wei, X. (2020). Changes in soil physical and hydraulic properties following the conversion of forest to cropland in the black soil region of Northeast China. Catena, 11(11)

Monde, A, N. Sinukaban, K. Murtilaksono, \& N. Pandjaitan. (2008). Dinamika karbon (C) akibat alih guna lahan hutan menjadi lahan petanian. J. Agroland, 15(1): 22-26

Murtinah, V., \& Komara, L. L. (2019). Distribusi unsur hara di dalam tanah dan biomassa tegakan jati verumur 8 tahun di Teluk Pandan Kabupaten Kutai Timur. Jurnal Pertanian Terpadu, 7(1), 100-111.

Murtinah, V., Edwin, M., \& Bane, O. (2017). Dampak kebakaran hutan terhadap sifat fisik dan kimia tanah di Taman Nasional Kutai, Kalimantan Timur. Jurnal Pertanian Terpadu, 5(2), 128-139.

Naharuddin, N. (2018). Sistem pertanian konservasi pola agroforestri dan hubungannya dengan tingkat erosi di wilayah Sub-DAS Wuno, DAS Palu, Sulawesi Tengah. Jurnal Wilayah dan Lingkungan, 6(3), 183-192.

Naharuddin, Rukmi, Wulandari, R., \& Paloloang, A. K. (2018). Surface runoff and erosion from agroforestry land use types. JAPS: Journal of Animal \& Plant Sciences, 28 (3): 875-882.

Naharuddin, Wahid, A., Rukmi, \& Sustri. (2019). Erosion hazard assessment in forest and land rehabilitation for managing the Tambun Watershed in Sulawesi, Indonesia. Journal of Chinese Soil and Water Conservation, 50 (3): 124-130. https://doi.org/10.29417/JCSWC.201909_50(3).0004

Nugroho, Y. (2009). Analisis sifat fisik-kimia dan kesuburan tanah pada lokasi rencana hutan tanaman industri pt prima multibuana. Hutan Tropis Borneo, 10(27), 222-229

Nurida, N. L., \& Kurnia, U. (2009). Perubahan agregat tanah pada Ultisols Jasinga terdegradasi akibat pengolahan tanah dan pemberian bahan organik. Jurnal Tanah dan Iklim, 30, 37-46.

Nursa'ban, M. (2006). Pengendalian erosi tanah sebagai upaya melestarikan kemampuan fungsi lingkungan. J. Geomedia. 4(2), $93-115$.

Pivić, R. N., Dinić, Z. S., Maksimović, J. S., Poštić, D. Ž., Štrbanović, R. T., \& StanojkovićSebić, A. B. (2020). Evaluation of trace elements MPC in agricultural soil using organic matter and clay content. Zbornik Matice srpske za prirodne nauke, (138), 97-108.

Power, J. F., \& Prasad, R. (1997). Soil fertility management for sustainable agriculture. CRC press.

Puja, I. N. (1989). Pengaruh kedalaman pengolahan tanah dan mulsa terhadap sifat fisik tanah dan hasil kedelai pada tanah mediteran merah kuning. Doctoral dissertation, Universitas Gadjah Mada, Yogyakarta. 
Putra, M. P., Edwin, M., \& Charlie, C. (2016). Analisis kandungan karbon tanah organik di Taman Botani Bukit Pelangi, Sangatta Kabupaten Kutai Timur. Jurnal Pertanian Terpadu, 4(1), 1-10.

Rauf, A., Rahmawaty, \& Wijoyo, H. (2015). Kajian karakteristik lahan kawasan relokasi pengungsi erupsi Gunung Sinabung Kabupaten Karo sebagai dasar penggunaan lahan berbasis pengelolaan DAS. Jurnal Pertanian Tropik, 2(1), 41-53.

Risamasu, R. G., \& Marlissa, I. (2020). Identifikasi karakteristik morfologi dan sifat fisik tanah akibat konversi penggunaan lahan berbeda di Negeri Hatu, Kecamatan Leihitu Barat. Jurnal Pertanian Kepulauan, 4(1), 46-55.

Song, W., \& Liu, M. (2017). Farmland conversion decreases regional and national land quality in China. Land Degradation \& Development, 28(2), 459-471.

Sugirahayu, L., \& Rusdiana, O. (2011). Perbandingan simpanan karbon pada beberapa penutupan lahan di Kabupaten Paser, Kalimantan Timur berdasarkan sifat fisik dan sifat kimia tanahnya. Jurnal Silvikultur Tropika, 2(3), 149-155.

Supriyadi, S. (2008). Kandungan bahan organik sebagai dasar pengelolaan tanah di lahan kering Madura. Jurnal Embryo, 5(2), 176-183.

Tangketasik, A., Wikarniti, N. M., Soniari, N. N., \& Narka, I. W. (2012). Kadar bahan organik tanah pada tanah sawah dan tegalan di Bali serta hubungannya dengan tekstur tanah. Agrotrop, 2(2), 101-107.

Tarigan, B., Sinarta, E., Guchi, H., \& Marbun, P. (2015). Evaluasi status bahan organik dan sifat fisik tanah (bobot isi, tekstur, suhu tanah) pada lahan tanaman kopi (coffea sp.) di beberapa kecamatan Kabupaten Dairi. Jurnal Agroekoteknologi Universitas Sumatera Utara, 3(1), 103-124.

Utomo, B. S., Nuraini, Y., \& Widianto, W. (2017). Kajian Kemantapan Agregat Tanah Pada Pemberian Beberapa Jenis Bahan Organik Di Perkebunan Kopi Robusta. Jurnal Tanah dan Sumberdaya Lahan, 2(1), 111-117.

Veldkamp, E., Schmidt, M., Powers, J. S., \& Corre, M. D. (2020). Deforestation and reforestation impacts on soils in the tropics. Nature Reviews Earth \& Environment, 1-16. 